stated that there is no diminution in the total energy production of the diabetic as compared with the normal man. The diabetic obtains his calorific energy from fat instend of from carbohydrates, and if fat is not given him in sufficient quantity to maintain his requirement he uses his own borly fat.

Pettenkofer and Toit in early experiments on a diabetic found no change in the metaholism from the normal. Rubner, using a phlorlizinized dog, found that the heat production was increased by 7 per cent. when glycosuria was induced. The protein metabolism was increased more than threefold, and he attributed the rise in energy production to the increased protein destruction (specific dynamic action of protein). Falta, working with Benedict in Bostom, conld find no evidence of an increased metabolism in diabetes mellitus. Du Bois and $V$ ecders report a comparison between the metabolism of a normal man and two men suffering from diabetes. One case, which was of the most severe type of diabetes, slowed an increase in metabolism of 5 per cent. above the normal. Finally, a preliminary report by $\mathrm{F} . \mathrm{G}$. Benedict and E. P. Joslin of work on the metabolism of thilteen patients representing various types of diabetes, declares that the heat production of the diabetic may bo 15 per cent. above the normal. Zuntz attributes this rise in metabolism to increased renal activity.

One must take to heart these lessons. The physician can be sure that he is treating his patient properly only when he knows that he is giving him at least the thirtyfive calories per kilogram required normally, and these must be contained in materials which the patient can oxidize. Protein will not give more than 10 or 15 per cent. of this requirement of cnergy. To give fat in sufficient quantity requires all the arts of cootiery. Here, as always, when the appetite is no longer a proper guide the physician's knowledge of the patient's requireritent is the only possible resource. When instinct fails science must be involked.

\section{RECENT ADVANCES IN THE TREATMENT OF DIABETES MELLITUS *}

\author{
GEORGE B. WALIJACE, M.D. \\ NEW YORK
}

In spite of all the experimental and clinical work on diabetes which has been done in the past years, a specific or etiologic treatment has not been attained. A striking advance has been made in dietetic treatment, however, and, with the clearer and more detailed knowledge of the metabolic derangement present, gained in the past few years, the general principles of dietetic therapy have undergone considerable modification and have been placed on a firmer foundation. Much yet remains unknown or obscure, but in no disease of metabolism can truly scientific dietetic treatment be more successfully carried out than in diabetes. It has been made clear, however, that no routine line of treatment, however sound it may be in principle, can be applied to all cases and that the treatment of one individual case may differ quite markedly from that of another. The

4. Falta : Wlen. klin. Wchnschr., 1000, xxil, No. 16.

5. DuBols, E. F., and Veeder, B. S. : Arch. Int. Med., 1910, v, 37.

* Read in the joint meeting of the Section on Pharmacology and Therapeutics and the Section on l'athology and Physlology of the St. Louis, June, 1010. future will undoubtedly show a more definite classification into groups or types than is at present possible.

Numerous attempts have been and are still being made to discover a specific for diabetes. Naturally this work centers in the preparation of glandular extracts, and although so far no success has been attained, some of the work may be briefly mentioned.

In 1907 Rennie and Fraser ${ }^{1}$ prepared an extract of the islands of Jangerhans of the pancreas of a certain genus of fish, the Teleosts. In these pancreas there is a chief island, large enough to be seen macroscopically. Five diabetic patients were treated with the extract and some improvement seemed to follow. The results have not been confirmed nor have additional cases been since reported by these authors. In the following year a paper by $/$ uel\%er" appeared in which were reported six cases treated with pancreas extract. The extract was made from dog's pancreas removed during the height of digestion. It was injected intravenously and the glycosuria diminished perceptibly during the two or three succeeding days. A decrease in the acetonuria was also observed. As a result of the injection fever usually occurred. The figures given by Zuelzer are not very convincing, however, and unfortunately the treatment in the hands of others has been disappointing.

Another line of treatment which attracted some attention was introduced by Moore and $\Lambda \mathrm{bram}^{3}$ in 1906. These investigators failed to find prosecretin in the duodenum of diabetics, and on this basis and the assumption that secretin might increase the internal secretion of the pancreas, employed an acid extract of the duodenal mucous membrane (secretin) in the treatment of a few cases of diabetes. Good results were recorded. Their conclusions were shortly afterwards attacked by Bainbridge who found that prosecretin was usually present in diabetics and that the administration of secretin failed to produce any effect on glycosuria. Bainbridge's work has been confirmed by Foster and others in this country.

In 1908 Minkowski again reported the effects of grafting pancreatic tissue in dogs. The graft, if it secures a sufficient blood-supply, grows and functions to such an extent that the animal's own pancreas can be completely removed without the occurrence of diabetes. Here would seem to be a great therapeutic possibility. But in animal experiments the transplantation must be made before diabetes has been induced, otherwise healing will not take place.

The interesting work of Cohnheim ${ }^{0}$ may be mentioned here. Colnheim found that the glycolysis occurring when an extract of muscle was added to sugar was increased if the further addition of an extract of pancreas be made. The extract of pancreas, he assumes, contains a substance of the nature of a hormone. The objection to his work, on the ground of bacterial contamination, seems to have been successfully met, and Hall, ${ }^{7}$ repeating his work, has obtained rather striking results. No attempt has been made by these investigators to apply their work to therapeutics, although it might appear to warrant such application.

1. Rennle and Fraser: Hlochem. Journ., 1007, 11, 7.

2. Zuelzer: Ztschr. f. exper. Path. u. Thernp., 1908, v, 300

3. Moore and Abram: Bjochem. Journ., 1000, 1, 28.

4. Bainbridge : Blochem. Jour., 1008, 111, 82.

5. Minkowski : Arch. 1. exper. Patb. u. Pharmakol. (Schmlede-

erg Fests(hr.), 1008, p. 395.

6. Cohnhelm: Ztschr. \&. physlol, Chem., 1003, xxxlx, 336 ; xlll, 401.

Hall : Am. Joar. Physiol., 1007, xvill, 283. 
A relationship between the function of the pancreas and other glands furnishing an internal secretion, especially the adrenals, has recently been demonstrated, and Eppinger, Falta and Rudinger ${ }^{8}$ have assumed that the seeretions of the thyroid and adrenals are of mutual aid in affecting metabolic processes, while each of these inhibits the pancreatic function and is in turn inhibited by it. On the basis of this assumption, Bruck ${ }^{0}$ has suggested that the serum of an animal deprived of its adrenals will have a beneficial effect in diabetes through lessening the adrenal action, which is excessive on account of the removal or diminution of the pancreatic secretion. Such a line of treatment seems absurd. However interesting and important the knowledge of the relationship between the various internal secretions may be, it offers at present no therapeutic application in diabetes.

There has come a tendency in recent years to a less frequent employment of drugs in diabetes therapy. Alcohol is still used to a large extent in the von Noorden clinic and elsewhere, but von Noorden himself has pointed out that amounts larger than 50 c.c. a day are not to be used. Its food value is of no great importance when taken in this quantity, and it is to be recommended chiefly as an aid to digestion, especially of fat. It would seem here that it is as a rule unnecessary, and while there may be some disadvantage in withdrawing it from those who are accustomed to its use, it must be remembered that diabetics seem especially susceptible to its injurious effects on the various organs of the body. It has been shown too that in some cases, at least, the tolerance for sugar is distinctly lessened by a too free use of alcohol. Neubauer ${ }^{10}$ has recently recommended alcohol as a means of warding off diabetic coma and reports cases in which the administration of fairly large doses, up to 135 c.c., has given good results. These doses are too large to be used for any length of time with safety, and, in fact, some other observers have failed to obtain any beneficial effects in this direction.

Considerable interest was aroused in this country by Rudisch's ${ }^{11}$ paper on the use of atropin in diabetes. Rudisch finds that atropin, when given in fairly large. amounts and in conjunction with dietetic treatment, is of great aid in lessening or preventing glycosuria. In the hands of others, however, it has not been so beneficial, and in a series of experiments I have carried out on depancreatized dogs it produced no effect whatever.

Thus it may be seen that little has been accomplished toward an etiologic or specific therapy and to find any actual progress we must turn to dietetic treatment.

There may be first considered here the question of the energy requirement in dinbetes. With tlie great appetite and marked loss in weight and strength so frequently seen in severe cases it is hardly surprising that the taking of large quantities of food should have scemed a necessity. And in spite of the tenching of those having the largest experience, the idea is still somewhat prevalent that diabeties have a much greater energy requirement and accordingly need a much greater supply of food than normal persons. The following out of this idea has undoubtedly led to considerable injury. The experiments of several investigators have shown that an increased energy requirement does not exist in diabetics. Quite recently a series of experiments carried

8. Epplnger, Falta and Rudinger: Ztschr. f. klin. Med., 1908, IXvi, 1 .

9. Bruck: Med. Klin., 1008, 1760 .
10. Neubauer: Munchen. med. Wchnschr., 1906, Ivili, 791.

11. Rudisch, J. : The Treatment of Diabetes Mellitus, THE JourNAL A. A. A., Oct. 29, 1009, p. 1360. out in accordance with most approved modern methods has been reported by DuBois and Veeder. ${ }^{12}$ They show that the energy requirement in diabetes is approximately 34 calories pro kilogram of body weight per day, which is no greater than that in a healthy man. Diets are generally arranged quantitatively, therefore, with the idea of supplying this amount of energy, due allowance being made for the loss through non-utilization of sugar. Over this point a controversy has arisen. Von Noorden ${ }^{13}$ states explicitly that the food-supply of a cliabetic must at least be equal to that of a healthy man of the same weight and under the same conditions. If less is taken a loss in weight is sure to occur. On the other hand, the opinion is often expressed that severe cases of diabetes may show a lowered level of energy requirement. Kolisch ${ }^{14}$ especially has stated that 25 calories pro kilogram weight may lead to an actual increase in body weight, and that in some cases as little as 20 calories may be taken with no loss in weight. $\mathrm{He}$ strongly advises the use of a minimum quantity of food, and claims that this offer's the best success in the treatment of severe cases.

In practice it is of course out of the question to determine what is the minimal energy requirement for each case, and the work done in this direction serves chiefly in establishing a principle of treatment. The conclusions which may be safely drawn are that high feeding is injurious, that in some cases of severe diabetes the minimal amount of food which will maintain the body weight brings about the best results, and that an amount equal to that required for a healthy man is generally to be recommended. Starvation days and prolonged periods of low diet are not unattended with danger and are to be prescribed only with due consideration of this.

Another subject of importance concerns the quality or class of food comprising the diet. In mild diabetes certain general principles may be laid down for practically all cases. First, the limit of tolerance for sugar is determined. This is done most easily by gradually increasing the daily amount of bread in the test ${ }^{25}$ diet until glycosuria reappears. The patient is then placed on a carbohydrate-free diet for at least two weeks. During this time the sugar tolerance will gradually increase and the hyperglycemia, which very frequently persists for some time after the urine is free of sugar, disappears. It is very rarely that acidosis of any dangerous degree occurs during this period. A mixed diet is now given and the new degree of sugar tolerance determined as before. In many cases it will be found that the tolerance approaches the normal; in others it may show only a slight increase, if any. In all cases, however, the subsequent diet should be such that the urine remains sugar-free and there should come at least once in three months a period of carbohydrate-free diet lasting one or two weeks. This treatment may seem quite unnecessary to a patient whose tolerance for sugar has become well-marked, but it should always be enforced.

In severe cases the qualitative arrangement of the diet is of greater importance. It has long been recog-

12. DuBols, E. F., and Veeder, B. S.: The Total Energy Requl . DuBols, plabetes Mellitus, Arch. Int. Med., 1910, v, 37.

13. Von Noolden: Handbuch d. Pnth. d. Stoffwechs., 1007, 11, 46.

14. Kollsch: Ztschr. f. phys. u. distet. Therap., 19u8, xil.

15. I employ the standard test dlet used in the von Noorden clinic for the determination of the severity of the case. This diet contalns 75 grams of white brend. The detalled det and the method of classifylng dlabetes Into mlld nnd severe forms are described by von Noorden in Clinical Treatises on the Pathology and Therayy of Disorders of Metabolism and Nutrition, E. B. Treat \& Co., N. Y., 1005 , part 7, p. 175 . 
nized that a glycosmia persisting under a carbohydratefree diet may be male to disappear if the protein of the food is cut down. Falta, Gigon ${ }^{10}$ and others have shown that some patients may have a marked susceptibility to protein; more so, in fact, than to carbolydrate; so that glycosuria may be lessened or at least not increased by cutting down the protein and at the same time adding carbohydrate. The fact is certainly now well established that high protein feeding is not desirable in severe eases. 'Two hundred grams of cooked meat per day is the maximum allowed by von Noorden and not more than 12 to $15 \mathrm{gm}$. of nitrogen should appear in the urine. The proteins of eggs and especially of vegetables, are to be preferred to those of meat since they affect the glycosuria less. It is on this account that periods of vegetable feeding are so beneficial.

With regard to carbohydrate feeding in scvere cases it is well known that most patients do better when one kind of starch is given alone than when several kinds are taken together. This is the basis for the rice, potato and oatmeal treatments. Of these the oatmeal treatment is of greatest importance. The manner of its action is not understood, but the benelicinl effects following its use are at times remarkable. All patients are not by any means, however, equally affected. Although it often brings about a decrease in glycosuria and an increase in sugar tolerance, its chief effect is in lessening acidosis. It is to be given alone, i. e., with no other carbohydrate, and in amounts of $250 \mathrm{gm}$. a day. ${ }^{17}$

Finally with regand to fat feeding, it is known that although the acetone bockies are formed chicfly from fats, their amount is uninfluenced by the amount of fat in the diet unless in enormous quantities. The lower fatty acids in butter should preferably be removed by washing.

Our knowledge concerning acidosis is as yet very incomplete. In a case in which complete sugar intolerance is present, acidosis may be slight. In another with slight glycosuria the acidosis may be marked. Allard ${ }^{18}$ has pointed out that in diabetic dogs the acidosis is not due to a non-utilization of carbohydrate, but probably to a pathologic state of the liver function. It seems estabjished that the condition is not an acidosis in the strict sense, but rather an intoxication due to specific poisons. Of these one at least we know-oxybutyric acid-and we know too that its salts are poisonous. Our efforts in treatment are directed toward preventing the excessive formation of these substances and in hastening their excretion. A strict protein diet increases the acetonuria, but if it can be persisted in an ultimate decrease may olten be obtained. So also the addition of carbohydrates to the dict lessens markedly the acidosis, although the glycosuria at once increases. Where coma is threatening, the glycosuria is of course of less importance than the diminution in acidosis. The introduction of periods of vegetable days, ${ }^{10}$ and of oatmeal feeding is especially beneficial in persistent acidosis. The action of sorium bicarbonate is chicfly that of increasing the excretion of oxybutyric acid, and one must not be misled by the presence of larger amounts of oxybutyric acid in the urine after its administration. To get the best ellects from this salt in severe acidosis it must be given in large amounts, $100 \mathrm{gm}$. or more a day. Where coma is present it should be given by intravenous injection.

10. Gigon: Mijnchen. med. Wchnschr., 1909, Ivl, 007 .

17. The oatmeal is given $\mathrm{ns}$ gruel; $200-300 \mathrm{gm}$. butter is usually taken also, and there may be added a few eggs and vegetables.

18. Allard: Arch. f. expel. P'ath. u. Pharmakol., 1008, $11 x, 338$.

10. The following vegetables may be uscd: asparagus, caull nower, string beans, Brussel sprouts, cabbage, sauer'siaut, silnach, lettuco, endives, ollves. In addition 4 to 6 eggs are taken dally.
In general the treatment of severe diabetes may be carried out along the following lines. It is as a rule practically impossible to keep the patient's urine sugarfree, and one should early give up the attempt. Since the main danger lies in the acidosis it is unwise to put the patient on a strict diet for any length of time. In the preliminary treatment there comes first a period of strict diet with 75 to $100 \mathrm{gm}$. of bread; then follows one of a low protein dict, consisting chiefly of vegetables, and finally one consisting of oatmeal. Each of these is of two or three days' duration. By repeating this procedure for two or three weeks there may be obtained a lowering of acilosis to such an extent that it ceases to be an immediate danger, and there may be obtained also a clear conception of the degree of sugar tolerance. The subsequent treatment is based on the results obtained. A carboliydrate-free diet can often be given for a week or so with marked general improvement. The patient is then allowed a small amount of carbohyclrate, or a more prolonged oatmeal or vegetable diet may be given. Every few weeks a period of strict protein-fat feeding of two or three days may be ordered, and once or twice a year a longer period, two or three weeks, should be tried. In conclusion it must be empluasized that no general rule can apply to all cases. Each case must be studied individually and only by such study can the proper line of treatment for any particular case be determined.

\section{THE ACTION OF GLYCOL ALDEHYD AND GLYCERIN ALDEHYD IN DIABETES MEL- LI'TUS AND 'THE NATURE OF ANTIKETOGENESIS *}

\section{R. T. WOODYATT, M.D. CHICAGO}

It is generally known that the acetone bodies (acetone, aceto-acetic acid and beta-oxybutyric acid) have their origin in butyric acid, which in turn comes from the fats and to a lesser extent from the proteins, and that the main prerequisite for development of acidosis is a diminution in sugar oxidation. When for any reason the daily oxidation of sugar in the body falls below a certain minimum (say 50 to $75 \mathrm{gm}$. per day for a man weighing 75 kilograms) then some degree of acidosis supervenes. In the acidosis of starvation, in which lowered sugar combustion is the result of a diminished intake of carboljydrate food, the mere administration of sugar serves to stop the accumulation of acetone bodies. In diabetes, in which the lessened oxidation of sugar is due to the inability on the part of the body to attack the glucose molecule, even when present in abundance, the administration of sugar has less effect than in other acidoses. But, though a diabetic cannot oxidize glucose, he may be able to oxidize other substances chemically allied thereto, such as gluconic acid, saccharic acid, alcohol, etc., and thus lower the existing acidosis. Sugars and allied substances which in oxidizing in the body have the power to lower acidosis are known as antiketogrenic substances.

- Rerd In the jolnt meeting of the Section on Pharmacology and Therapeutics and the Section on P'athology and r'hyslology, at the Stxty-lirst Annual Session, beld at St. Louis, June, 1910.

- The origlnal incentive to do this work was received in Munlch. When worling on the oxldation of glycerin in the second medical clinic of the university, some glycerin nldehyd was prepared, which, at the suggestion of Dr. Otto Neubaner, assistant to l'rof. F. Miller, at the suggestion of Dr. Otto Neubauer, assistant to I'rof. F. Miller,
was fed to a diabetic patient then under observation. Later development of the work was done in Chichgo in the Iedical Department or leusb Medical College (Professor Billings). 